\title{
Getting Past Privacy? Surveillance, the Charter, and the Rule of Law
}

\author{
Lisa M. Austin \\ Version Post-print/accepted manuscript \\ Citation Lisa Austin, "Getting Past Privacy? Surveillance, the Charter, and the \\ (published version) Rule of Law" (2012) 27 Canadian Journal of Law and Society 381-398. \\ Publisher's Statement Lisa Austin, "Getting Past Privacy? Surveillance, the Charter, and the \\ Rule of Law" (2012) 27 Canadian Journal of Law and Society 381-398. \\ Copyright (C) [2012]. Reprinted by permission of Cambridge University \\ Press. https://doi.org/10.1017/s0829320100010565
}

How to cite TSpace items

Always cite the published version, so the author(s) will receive recognition through services that track citation counts, e.g. Scopus. If you need to cite the page number of the author manuscript from TSpace because you cannot access the published version, then cite the TSpace version in addition to the published version using the permanent URI (handle) found on the record page.

This article was made openly accessible by $U$ of $T$ Faculty. Please tell us how this access benefits you. Your story matters. 


\title{
Getting Past Privacy? Surveillance, the Charter, and the Rule of Law
}

\author{
Lisa M. Austin*
}

\section{Introduction}

In 2010, the Supreme Court of Canada held that the police did not need a warrant to request that a utility company install a digital recording anmeter (DRA) to measure electricity consumption patterns in a specified residence. ${ }^{1}$ In fact, this requested installation did not constitute a search or seizure at all, and so constitutional concerns regarding privacy were not engaged. The implications of this finding are that such requests are entirely a matter of police discretion and need not even meet a test of reasonable suspicion, applied either before or after the fact. Gomboc is not an outlier. It is consistent with other cases, decided either by the Supreme Court or lower courts, which permit police to look through garbage, ${ }^{2}$ access airline passenger information, ${ }^{3}$ or gain subscriber information from telecommunication providers without any form of constitutional oversight. ${ }^{4}$ In all of these cases, the courts have held that there is no reasonable expectation of privacy in the information in question. The reasons given have included the fact that this information was not part of one's "biographical core," that it was accessible to others, or that the terms of the relationship with the third party were such that any expectation of privacy

\footnotetext{
- Associate Professor, University of Toronto Faculty of Law. I would like to thank Hamish Stewart for his excellent comments on an earlier draft. An earlier version of this paper was presented at the Queen's University conference "The Expanding Surveillance Net: Ten Years after 9/11" (September 8-9, 2011) and I am grateful to the comments of the participants. I would also like to thank the participants of two other events for their helpful input on earlier iterations of some of the ideas presented here: Melbourne Law School's conference "Media, Communications and Public Speech" where I gave a talk entitled "Privacy: Rights, Risks and the Rule of Law" (November 25, 2010) and the University of Toronto Faculty of Law's Law Lab (March 4, 2011).

${ }^{1} R v$ Gomboc, 2010 SCC 55.

${ }^{2} R v$ Patrick, 2009 SCC 17.

${ }^{3} R v$ Chehil, 2009 NSCA 111.

${ }^{4} R v$ Ward, 2008 ONCJ 355; $R v$ Cuttell, 2009 ONCJ 471.
} 
was severely diminished. ${ }^{5}$ What these cases show is the poverty of Canada's constitutional framework for dealing with the emerging forms of surveillance that others in this collection have so carefully catalogued - many of which involve the gathering of precisely this kind of information.

It is tempting to take these cases and conclude the problem is with the idea of privacy. This has certainly been a persistent theme in Surveillance Studies, where privacy has been criticized as a limited, legalistic, and highly individualized notion. ${ }^{6}$ While there is much that is helpful in these critiques of privacy, in this paper I want to "lawyer-up" and propose a richer legal understanding of privacy. The reasons for doing so are both practical and theoretical. The practical reason lies in the fact that so often public policy debates regarding government actions get framed, either explicitly or implicitly, in terms of "Charter-compliance.” For example, if proposed legislation is criticized for its impact on privacy, the response that it is Charter compliant is often provided as a way to end the policy debate rather than simply as one aspect of the conversation. ${ }^{7}$ Expanding the legal idea of privacy is therefore a practical way of opening up the public policy debate to a broader range of concerns.

\footnotetext{
${ }^{5}$ In the subscriber information cases this was because of terms of the standard form service agreements indicated that the service provider might share information with the police. In Gomboc, supra note 1, the terms of the relationship were set out in a regulation that permitted the utility to share information with the police unless the customer specifically requested confidentiality.

${ }^{6}$ For an excellent overview of this debate, see Colin J. Bennet, "In Defence of Privacy: The Concept and the Regime" (2011) 8 Surveillance and Society 485 and the articles in the same issue responding to Bennet's claims. ${ }^{7}$ See e.g. CBC News, "Lawful access FAQs: Clearing confusion about "surveillance" proposals" October 5, 2011 (http://www.cbc.ca/news/politics/story/2011/10/04/f-lawful-access.html).
} 
The theoretical reason for focusing on our legal understanding of privacy is to show how the idea of a reasonable expectation of privacy in our legal discourse is bound up with other legal ideas and partially constituted by them. We cannot read privacy jurisprudence and conceptualize privacy simply as a value protected by law and legal processes as if it can be neatly separated from these. In particular, I will argue that historically privacy was rooted in ideas of the rule of law. In this sense, I do advocate for getting past the language of privacy in its current form but in order to connect privacy back to an earlier rule of law tradition from which it sprang and find there the tools needed to reinvigorate our legal discourse.

There are many different accounts of the rule of law. ${ }^{8}$ Some focus on procedural requirements, others include a robust set of substantive rights; some connect the rule of law to the very idea of law, others consider it one of law's virtues that make it effective. ${ }^{9}$ Nonetheless, despite these differences there is widespread agreement that any account of the rule of law will include a number of core elements. These elements were well expressed as the eight principles of legality outlined by Lon Fuller in The Morality of Law: generality, publicity, nonretroactivity, clarity, noncontradiction, possibility of compliance, stability, and congruence between official action and declared rule. ${ }^{10}$ Even critics of Fuller's position that these principles constituted the "inner morality" of law agree that these principles form the core of the rule of law. Moreover, despite the various accounts of what unified these various principles two basic ideas are prevalent: that the rule of law provides constraints on the arbitrary exercise of power and that the rule of law

\footnotetext{
${ }^{8}$ Jeremy Waldron, "Is the Rule of Law an Essentially Contested Concept (in Florida)?" (2002) 21 Law and Phil 137; Brian Z. Tamanaha, On The Rule of Law: History, Politics, Theory (Cambridge: Cambridge University Press, 2004). 9 Jeremy Waldron, "The Concept and the Rule of Law" (2008) 43 Ga L Rev 1; Joseph Raz, "The Rule of Law and Its Virtue” (1977) 93 LQR 195.

${ }^{10}$ Lon L. Fuller, The Morality of Law, revised edition (New Haven and London: Yale University Press, 1969).
} 
permits individuals to plan their activities in light of knowledge of legal liability. ${ }^{11}$ It is these twin ideas, and their expression through the basic principles of legality, that I mean to invoke in this paper.

My argument is that these core aspects of the rule of law have implicitly shaped our legal definition of privacy but have done so in a partial manner and in a manner that supports a narrow conception of privacy. The ironic consequence is that the legal discourse of privacy now often helps to support the expansion of the discretionary authority of state agents rather than works to constrain it - undermining rather than upholding the rule of law. In order to be more responsive to new forms of surveillance, our privacy jurisprudence requires a more explicit focus and richer understanding of the demands of these core rule of law principles.

\section{The Significance of Trespass}

Canada's constitutional discourse regarding privacy starts with Hunter $v$ Southam, one of the first Charter cases decided by the Supreme Court of Canada, and the very first to interpret s.8's guarantee of the "right to be secure against unreasonable search or seizure."12 Arguing for a broad and purposive approach to Charter interpretation, Justice Dickson held that before one could assess the reasonableness of a search, one had to determine the underlying interest protected by s.8. Noting the historical roots of search and seizure law lay in "the right to enjoy property," Justice Dickson sided with the U.S. Supreme Court's approach to the Fourth

\footnotetext{
${ }^{11}$ Some put these two ideas together. See Raz, supra note 9.

${ }^{12}$ Hunter v Southam, [1984] 2 SCR 145.
} 
Amendment in rejecting any necessary link with trespass and instead held that the Constitution protects a right to privacy. ${ }^{13} \mathrm{He}$ viewed this as having a "wider ambit" than the interests protected in the earlier trespass cases, and also was clear that the interests protected might go beyond the right to privacy. ${ }^{14}$

In this section I will examine one of the trespass cases that Justice Dickson found too narrow and argue that we can also locate in it a different set of legal ideas that are not merely about "the right to enjoy property." 15 In particular, we can find a strong concern for placing limits on the arbitrary use of governmental authority, a concern more properly labeled as an aspect of the rule of law. To say that this is fully captured by ideas of property is to miss its importance and limit its impact. The legacy of this property interpretation is that, in the move from property to privacy, the constitutional jurisprudence regarding unreasonable search and seizure has relegated rule of law ideas to the shadows where its influence must find distorted expression through the language of privacy.

The trespass case explicitly mentioned by Justice Dickson was the $18^{\text {th }}$ century British case Entick $v$ Carrington, in which the plaintiff brought a trespass action against the defendants in relation to a search of his house. ${ }^{16}$ The court, finding for the plaintiff, stated: "our law holds the property of every man so sacred, that no man can set his foot upon his neighbour's close without

\footnotetext{
${ }^{13}$ The text of the US Fourth Amendment is: "The right of the people to be secure in their persons, houses, papers, and effects, against unreasonable searches and seizures, shall not be violated, and no Warrants shall issue, but upon probable cause, supported by Oath or affirmation, and particularly describing the place to be searched, and the persons or things to be seized."

${ }^{14}$ Hunter $v$ Southam, supra note 12 at 158-9.

${ }^{15}$ Ibid at 157.

${ }^{16}$ Entick v Carrington, 95 ER 807 (King’s Bench) 1765.
} 
his leave; if he does he is a trespasser, though he does no damage at all; if he will tread upon his neighbour's ground, he must justify it by law." ${ }^{\text {"17 }}$ When looked at through the "broad, purposive analysis" of constitutional interpretation it is easy to see why Justice Dickson focused on this aspect of the case and then endeavoured to provide a broader sense of the individual interest at stake. However, if we return to the case in more detail we can see that a focus on the individual entitlement protected (property) was only part of a larger concern regarding the exercise of state authority.

John Entick was accused of seditious libel and a general warrant was issued authorizing several individuals "to make strict and diligent search for John Entick, the author, or one concerned in the writing of several weekly very seditious papers, entitled The Monitor, or British Freeholder... and him having found, you are to seize and apprehend, and to bring, together with his books and papers, in safe custody before me to be examined concerning the premises, and further dealt with according to law." 18 The breadth of such a warrant is striking and, placed in the context of a prosecution for statements of political dissent ("gross and scandalous reflections and invectives upon His Majesty's Government, and upon both Houses of Parliament”), its use engages a broad set of concerns regarding liberty and the abuse of state power.

${ }^{17}$ Ibid. Cited in Hunter $v$ Southam, supra note 12 at 158 (per Dickson J).

${ }^{18} \mathrm{Ibid}$. Wilkes was the other high profile case concerning the use of general warrants and seditious libel, which is acknowledged to have a great influence on the drafting of the Fourth Amendment in the US constitution. See Wilkes $v$ Wood, (1763) 98 ER 489 (KB). 
These larger concerns are indeed what animated the court's argument that the common law did not recognize the power to grant such a general warrant. Consider what precedes the statement regarding property's “sacred” status in English common law:

The warrant in our case was an execution in the first instance, without any previous summons, examination, hearing the plaintiff, or proof that he was the author of the supposed libels; a power claimed by no other magistrate whatever...; it was left to the discretion of these defendants to execute the warrant in the absence or presence of the plaintiff, when he might have no witness present to see what they did; for they were to seize all papers, bank bills or any other valuable papers they might take away if they were so disposed; there might be nobody to detect them. ${ }^{19}$

Then, just after the sacredness of property statement: "we can safely say there is no law in this country to justify the defendants in what they have done; if there was, it would destroy all the comforts of society; for papers are often the dearest property a man can have."20

Several things are important here. First, looking at the statements that precede the sacredness of property we can see a concern regarding the absence of anything that we might call procedural fairness or accountability in granting the warrant or its execution. Second, looking at the statements that follow the sacredness of property we can see a concern for the broader systemic effects of recognizing such warrants as justification for trespass - that the effect would be to undermine the "comforts of society." Placed within this context, the sacredness of property is more about the question of limits on state authority than about the nature of the individual

${ }^{19}$ Ibid.
${ }^{20}$ Ibid. 
interest protected. The central idea is that state agents must act within the terms of existing law, such as the laws of trespass. ${ }^{21}$ If they go beyond the terms of existing law-such as entering a home without the consent of the owner - then they require special justification. Here, the court refused to uphold the validity of the general warrant as providing that justification, given its lack of safeguards and its potential, if systematically available, to undermine important aspects of the social order. These concerns are not well-captured by the language of "the right to enjoy property." They are more accurately labeled as rule of law concerns regarding constraints on the arbitrary exercise of state authority.

It was British cases like Entick v Carrington, involving the use of general warrants in the context of seditious libel prosecutions, which influenced the framers of the United States Constitution and the drafting of the Fourth Amendment. ${ }^{22}$ Indeed, several recent commentators have argued that current Fourth Amendment interpretation would be improved if courts attended to the fact that "[the Fourth Amendment was ... adopted for the purpose of checking discretionary police authority." ${ }^{, 2}$ Yet it is exactly this concern regarding discretionary police authority that takes a backseat to the language of privacy once Justice Dickson interpreted Entick as a narrow case about "the right to enjoy property" and instead placed s.8 jurisprudence within the "wider ambit" of privacy protection.

\footnotetext{
${ }^{21}$ Note that there was no professional police force at the time.

${ }^{22}$ For an overview of the history of the Fourth Amendment, including different interpretations of this history, see Thomas Y Davies, "Recovering the Original Fourth Amendment" (1999) 98 Mich L Rev.547.

${ }^{23}$ The Honorable M. Blane Michael, "Reading the Fourth Amendment: Guidance From the Mischief that Gave it Birth” (2010) 85 NYUL Rev 905. See also Davies, supra note 22.
} 
Despite the marginal role of explicit rule of law values in s. 8 interpretation, there is legal precedent for rethinking its significance quite apart from returning to cases such as Entick or examining the historical roots of the American Fourth Amendment. The rule of law finds direct expression within the preamble to the Charter, which states: "Whereas Canada is founded upon principles that recognize the supremacy of God and the rule of law." The Supreme Court of Canada has also indicated that the rule of law is part of the understanding of the "principles of fundamental justice" under s. 7 of the Charter. ${ }^{24}$ This is significant for discussions of s. 8 of the Charter, since the Supreme Court has stated generally that ss.8-14 of the Charter are specific expressions of s.7, "instances in which the "right" to life, liberty and security of the person would be violated in a manner which is not in accordance with the principles of fundamental justice. ${ }^{, 25}$ While this connection between s. 7 and s. 8 has been left unexplored in s. 8 jurisprudence, one could argue that an "unreasonable search and seizure" is one that violates basic principles of the rule of law. And although the Court adopted the language of privacy as its framework for s. 8 analysis, it has also stated that other values might also be protected—values that could include the rule of law.

Although the relationship between s. 8 and the rule of law has not been elaborated upon within Canadian jurisprudence, the Supreme Court of Canada has discussed the relation between s.7 and the rule of law in its case law regarding vagueness. The statement of principle that came out of the leading Canadian case is that "a law will be found unconstitutionally vague if it so lacks in

\footnotetext{
${ }^{24}$ Section 7 states: "Everyone has the right to life, liberty and security of the person and the right not to be deprived thereof except in accordance with the principles of fundamental justice." See Re BC Motor Vehicle Act, [1985] 2 SCR 486 at para 63.

${ }^{25}$ Ibid at para 29.
} 
precision as not to give sufficient guidance for legal debate." 26 This idea of "sufficient guidance for legal debate" has two aspects: first, whether the law can perform its function of guiding individual actions through fair notice and second, whether the law is capable of constraining enforcement discretion. Constitutional jurisprudence in the United States also lists these as the two aspects of the rule of law raised by vague laws. Indeed, they are the two basic aspects of the rule of law already identified.

There is a strong tradition of understanding the value of the rule of law in terms of its ability to guide action. ${ }^{27}$ According to this view, what is central to the rule of law is the ability of individuals to plan their activities in light of potential legal liability. Values such as predictability of expectations are central to this understanding. This planning role has been linked to an idea of legal liberty but also to ideas of autonomy and dignity. From this perspective, one of the defects of vague laws is that they do not provide adequate notice to individuals regarding which activities will render them subject to prosecution. ${ }^{28}$

A concern for discretionary authority focuses on the idea of the rule of law as a limit to arbitrariness and discretionary power. ${ }^{29}$ There are a number of different ways one can think about this. For example, one could argue that the rule of law invokes an idea that power should be regulated by law. In other words, law is an ideal that should be understood as the very contrast to ideas of

\footnotetext{
${ }^{26} R v$ Nova Scotia Pharmaceutical Society, [1992] 2 SCR 606.

${ }^{27}$ Joseph Raz is one of the strongest proponents of this view. See Raz, supra note 9.

${ }^{28}$ See Papachristou $v$ City of Jacksonville, 405 US (1972).

${ }^{29}$ For example, AV Dicey made this part of his understanding of the rule of law: AV Dicey, Introduction to the Law of the Constitution, 10th ed (London: Macmillan, 1959) But note that this was one of the reasons that Dicey was opposed to the rise of the administrative state.
} 
arbitrariness and discretionary power. If one takes a more instrumentalist approach, one could argue that broad discretion makes various abuses more likely. To take the vagueness cases as an example, if a law is too vague then this effectively confers a broad discretion on law enforcement officers in relation to how, and against whom, they apply the law. For example, in finding a requirement of providing "credible and reliable identification" void for vagueness the United States Supreme Court has stated:
Although the doctrine focuses both on actual notice to citizens and arbitrary enforcement, we have recognized recently that the more important aspect of the vagueness doctrine "is not actual notice, but the other principal element of the doctrine-the requirement that a legislature establish minimal guidelines to govern law enforcement." ... Where the legislature fails to provide such minimal guidelines, a criminal statute may permit "a standardless sweep [that] allows policemen, prosecutors, and juries to pursue their personal predilections." ${ }^{30}$

This emphasis on constraining law enforcement discretion is also one of the Canadian Supreme Court's concerns, although they do not put it so clearly. However, a closer examination of the reasons that the Court gives for the importance of a law providing "sufficient guidance for legal debate" reveals that this idea of "legal debate" encompasses both concerns related to notice to citizens and concerns related to controlling law enforcement discretion. As the court states, "[i]n giving unfettered discretion, it will deprive the judiciary of means of controlling the exercise of this discretion." 31

\footnotetext{
${ }^{30}$ Kolender v Lawson, 461 US 352 (1983), internal references removed.

${ }^{31}$ Nova Scotia Pharmaceutical, supra note 26.
} 
Although the ideas of fair notice and constraints on the discretionary authority of law enforcement are explicitly discussed within areas of $\mathrm{s} .7$ jurisprudence, they remain implicit rather than explicit within s.8's reasonable expectation of privacy test. I will argue that making these ideas explicit is important in order to overcome some of the current deficiencies in the ability of s. 8 to come to terms with contemporary forms of state surveillance. However, in the following section I will show how one particular articulation of the rule of law-the idea that agents of the state must act within the law absent special authorization—-has implicitly operated to help shape and support a very narrow view of constitutional privacy protection. In other words, we cannot understand the narrow legal idea of privacy that we have without understanding the role played by the rule of law in its articulation. But once we see this, we can also see that the debate that needs to happen is not simply a debate about the concept of privacy but also about how best to understand the core demands of the rule of law.

\section{Privacy and the Rule of Law}

Since Hunter $v$ Southam, "privacy" has been the central organizing idea for determining when a search or seizure is unreasonable. Police action constitutes a search or seizure when it violates a reasonable expectation of privacy and this will only be reasonable where certain procedural safeguards in place, such as prior authorization (a warrant) granted on a standard of reasonable and probable grounds that there is evidence in the particular place to be searched. Some departures from these standards are permissible, depending on how the court views the appropriate balance between an individual's interest in privacy and state objectives such as law enforcement in the particular context. Procedural safeguards have always been a part of what 
makes a search or seizure reasonable and these procedural safeguards can themselves be thought to protect rule of law values. But in what follows I want to show that these values do not just come in as part of what it means to achieve a proportionate balance between privacy and state objectives. I want to show that these values in fact infuse the very manner in which privacy is defined by the Supreme Court and, in particular, have helped to create a narrow view of privacy that is heavily indebted to ideas of property and confidentiality.

The rule of law legacy of a case like Entick lies in the idea that agents of the state, just like ordinary citizens, must follow the law unless they have specific authorization for departing from it. The obverse of this is to say that the police are permitted to do what other citizens are permitted to do. This is the role that the law of trespass played in cases like Entick—nobody is permitted to enter another's property without permission. State authorities are not above the ordinary law, therefore they require special authorization to enter. But once courts move from property to privacy, this analysis runs into difficulties for there is no clear and well-developed understanding of the right of privacy in private law that could play a similar role to trespass in delimiting the boundaries of permissible intrusions. ${ }^{32}$

Indeed, it is telling that the jurisprudential language of privacy that developed is one of "reasonable expectations" rather than "rights." There is an affinity between the rule of law values of fair notice and individual planning and the protection of settled expectations. The idea that expectations can operate to limit the exercise of state authority is one that finds its clearest legal

${ }^{32}$ See Lisa M Austin, "Privacy and Private Law: The Dilemma of Justification” (2010) 55 McGIll LJ 165. 
articulation in administrative law and is understood to be rooted in rule of law values. ${ }^{33}$ This doctrine of "legitimate expectations," more developed in the UK than in Canada, protects individual expectations created through administrative decisions and representations, in a variety of ways including the application of principles of procedural fairness. Although the reasonable expectation of privacy doctrine does not borrow from this area of administrative law, it is interesting to note both the rule of law foundations of the doctrine of legitimate expectations and the fact that it is not necessarily about protecting individual rights but rather settled expectations that permit an individual to plan activities and anticipate legal liability. ${ }^{34}$

The administrative doctrine of legitimate expectations focuses on expectations that the state has participated in creating, whereas the doctrine of a reasonable expectation of privacy focuses on expectations that everyone - private citizens and police alike - should honor. This has led to two tendencies in the jurisprudence. The first, most evident in a number of early cases, is a descriptive account of what people expect in different contexts. ${ }^{35}$ Although prevalent as an approach, particularly in earlier jurisprudence, the Supreme Court of Canada has been moving away from such a descriptive account. In $R v$ Tessling, the Supreme Court stated that the reasonable expectation of privacy test is a normative rather than a descriptive standard and, after canvassing past case law, developed a set of factors that must be taken into account in determining whether such an expectation exists. The Tessling factors illustrate the second tendency of the jurisprudence, which is to fall back on ideas of property and confidentiality when

\footnotetext{
${ }^{33}$ Soren Schonberg, Legitimate Expectations in Administrative Law (Oxford: Oxford University Press, 2000) at 12 ff.

${ }^{34}$ Ideas of procedural fairness in administrative law are not necessarily tethered to ideas of individual rights, but can be required where important interests, privileges or expectations are also at stake.

${ }^{35}$ See Lisa M Austin, "Privacy and the Question of Technology" (2003) 22 Law \& Phil 119 for a critique.
} 
determining the boundaries of privacy — ideas that are much more well developed than privacy in terms of private law doctrine and so can more easily fulfill the function that I have been describing as delineating actions that nobody—police or private citizen—is permitted to do absent specific authorization or justification.

The Tessling decision remains the analytical framework for determining a reasonable expectation of privacy for the purposes of s. 8 of the Charter. Although Tessling confirms earlier cases requiring both a subjective and objective expectation of privacy, the key set of factors concerns the objective expectation. The case, and subsequent jurisprudence, does not attempt to organize these factors, but they can be usefully categorized in terms of "privacy factors," "discount factors" and "proportionality factors" as follows:

\section{Privacy Factors}

- Place where search occurred

- Was the information intimate or biographical in nature?

\section{Discount Factors}

- Was the subject matter in public view?

- Was the subject matter abandoned?

- Was the information in hands of third parties; if so, was it subject to an obligation of confidentiality?

\section{Proportionality Factors}

- Was the police technique intrusive in relation to the privacy interest? 
- Was the use of surveillance technology itself objectively unreasonable?

From this list we can see that the two key factors for defining a privacy interest are the ideas of "place" and "biographical core." The remaining factors either function to discount the privacy interest defined through these twin ideas, or function to assess whether the means chosen to impinge upon privacy are minimally impairing of the interest.

The cases that elaborate on the nature of place are heavily influenced by property ideas such as control over access to the space in question and highlight the ongoing influence of property. ${ }^{36}$ The "discount factors" listed above are also heavily influenced by ideas of property and confidentiality. What is in "public view" often refers to what someone can see from a public place, such as a sidewalk. The idea of abandonment is originally a property idea that concerns relinquishing one's possessory rights (rights of control) in relation to an object of personal property. Sharing information with a third party diminishes one's privacy interest in that information unless it is protected by an obligation of confidentiality.

These privacy and discount factors combine to support a very narrow understanding of privacy that provides the strongest protection to closely held secrets and activities within the home. The tenacity of such a narrow understanding of privacy seems puzzling when part of a broad and purposive interpretation of a constitutional guarantee against unreasonable search and seizure, especially one that was originally intended to be of "wider ambit" than trespass. However, as I

\footnotetext{
${ }^{36} R v$ Edwards, [1996] 1 SCR 128, is the strongest example, which Binnie J relies on heavily in Tessling. In $R v$ Dyment, [1988] 2 SCR 417, LaForest focused instead on the nature of the social relations that occur in various places, but this is not a point that has received any notable further development although it is sometimes restated.
} 
have been arguing, one way to understand the persistence of these ideas in the jurisprudence is not through the special nature of property interests or confidential relationships but through the rule of law idea that the police must respect existing law (such as property rights and obligations of confidence) and the settled expectations that derive from this. In other words, the police are permitted to do what private citizens are permitted to do and it is only when they go beyond this that they require special authorization.

If part of the persistence of a narrow view of privacy is explained through the influence of one particular articulation of rule of law values - that the police should, absent special authorization, respect existing laws and settled expectations - then this suggests that a critique of this narrow view of privacy must go beyond simply attacking the concept of privacy; it must also show how the core values of the rule of law demand a different articulation of the protection offered by s. 8 of the Charter. In other words, Canada's privacy jurisprudence needs a more robust understanding of what is demanded by the rule of law in the context of state surveillance.

One place to start such a project is to critically re-examine the idea of a "biographical core"perhaps the most important privacy factor across a range of cases - and the departure from it in several recent cases. One's biographical core is information "which individuals in a free and democratic society would wish to maintain and control from dissemination to the state. This would include information which tends to reveal intimate details of the lifestyle and personal choices of the individual." ${ }^{, 37}$ The original iteration of this idea is even broader. In Thomas Newspapers Justice La Forest argues that personal papers are different from business records because they contain information "about one's lifestyle, intimate relations or political or

${ }^{37} R v$ Plant, [1993] 3 SCR 281 at 293 per Sopinka J; cited in Tessling at para 15. Emphasis added. 
religious opinions. ${ }^{, 38}$ Moreover, he places this idea of personal information directly in relation to the state:

It is for the individual to decide what persons or groups he or she will associate with, what books he or she will read, and so on. One does not have to look far in history to find examples of how the mere possibility of the intervention of the eyes and ears of the state can undermine the security and confidence that are essential to the meaningful exercise of the right to make such choices. ${ }^{39}$

The idea here is not simply that the state must act in the same way as everyone else but that there are special concerns raised regarding the state getting ready access to some forms of information. Instead of delineating a zone of privacy defined independently of the state, which agents of the state must respect, the idea of a biographical core is defined in relation to the state and special vulnerabilities to state abuse. This takes us away from a focus on the fact that the state should respect existing law and expectations and instead focuses on a different kind of abuse that we need to be concerned with.

This can help illuminate the most recent departures from the biographical core analysis that have broadened the potential scope of informational privacy. Two Supreme Court of Canada cases have indicated a shift away from this "biographical core" analysis and have done so in circumstances that are quite interesting, from a privacy perspective. $R v A M$ concerned the constitutionality of the warrantless use of sniffer dogs to search for drugs in student backpacks

\footnotetext{
${ }^{38}$ Thomson Newspapers Ltd $v$ Canada (Director of Investigation and Research, Restrictive Trade Practices Commission), [1990] 1 SCR 425 at 517. Although La Forest J was not in the majority in Thomson, his statements were cited with approval by Sopinka and Iacoboccui JJ in British Columbia Securities Commission v Branch, [1995] 2 SCR 3 at para 62 and by Iacobucci J and McLachlin CJC in R. v. Mills, [1999] 3 SCR 668 at para 80.

39 Thomson, supra note 38.
} 
and Gomboc, already mentioned, concerned the constitutionality of the warrantless use of a digital recording anmeter (DRA) to record electricity consumption in a house. In both cases the investigative technique at issue (sniffer dogs, DRA) meant essentially that the police could determine the one thing they were interested in (drugs, marijuana grow-op) with a great deal of accuracy but could not really learn much else about the person under investigation (they wouldn't know what else was in the backpack or what other sorts of activities were going on within the home). ${ }^{40}$ It would seem that these would both fail the biographical core analysis. However, several of the judges indicated a shift away from the biographical core analysis in order to accommodate these types of cases.

This shift is ambiguous, for it still retains many elements of the other Tessling factors, including an emphasis on whether the information at issue was under the control of the accused rather than being abandoned. However, one of the factors that influenced some members of the court in $R v$ $A M$ was that "[ $\mathrm{t}]$ he information is highly meaningful ... The dogs pointed the police to the sniffer dog's equivalent of a smoking gun." ${ }^{41}$ Similarly, in Gomboc the DRA device was seen by several of the judges as "intrusive enough to yield usually reliable inferences as to the presence within the home of one particular activity: a marijuana grow operation." ${ }^{, 42}$ Such an inference would provide enough evidence to get a search warrant for the premises. Information is protected, therefore, because it is specific and meaningful and not because it falls within one's biographical core.

\footnotetext{
${ }^{40}$ There was some dispute about this in Gomboc with several of the judges arguing that the information could yield other inferences about activities within the home.

${ }^{41} R v A M, 2008$ SCC 19 at para 37.

${ }^{42}$ Gomboc, supra note 1 at para 81 per Abella J; see also the reasons given by McLachlin CJC and Fish J at para 129.
} 
The idea, and significance, of specific and meaningful information does not fit within the existing framework of privacy that has focused on ideas of place and one's biographical core. However, obtaining such information does make an individual vulnerable to the further exercise of state authority in a fairly immediate manner (more intrusive searches, arrest). Therefore it is similar to the concerns that originally motivated the biographical core analysis, as outlined above: there are some situations where individuals are especially vulnerable in relation to the exercise of state investigatory power and require procedural safeguards to prevent abuses. Broad discretion is problematic in such contexts as it gives rise to concerns regarding arbitrary and even discriminatory use. The language of the rule of law is far more illuminating of such concerns than the language of privacy.

\section{Surveillance as a Rule of Law Problem}

As outlined in the previous section, rule of law values are not simply the kinds of procedural safeguards that come into play once privacy is impinged upon-rule of law values inform the very definition of privacy in constitutional jurisprudence. However, the fact they have done so largely implicitly and only partially is problematic. One of those problems is that, as I have argued, the partial expression of rule of law values has helped to entrench a narrow view of privacy that is heavily focused upon ideas of "expectations" as well as ideas of property and confidentiality. As this section will outline, this framework for discussing privacy does not provide space for other rule of law concerns to come to light and be discussed explicitly, which means that they either go unaddressed or are seen only through the distorting lens of the existing privacy test. 
One of the ironic results of not understanding the rule of law roots of the reasonable expectation of privacy test is that the idea of "expectations" and, more particularly, the factors that are taken to undermine such expectations, end up expanding the scope of discretionary authority rather than limiting it without even addressing the rule of law concerns that attend such an expansion. This is evident in $R v$ Patrick, where the Supreme Court of Canada held that there was no reasonable expectation of privacy in garbage enclosed in an opaque bag and put out for pickup. ${ }^{43}$ Although acknowledged as a "bag of information," it was considered abandoned when placed for collection: "The bags were unprotected and within easy reach of anyone walking by in a public alleyway, including street people, bottle pickers, urban foragers, nosey neighbours and mischievous children, not to mention dogs and assorted wildlife, as well as the garbage collectors and the police. ${ }^{, 44}$ Because abandoned, there was no expectation of privacy in their contents. But by framing the central issue in the case as one of abandonment, two key issues do not find clear expression. The first is that the assorted scavengers whom Justice Binnie suggests could open the garbage bags with impunity were in fact prohibited from doing so by a City of Calgary bylaw. ${ }^{45}$ In other words, the result of this case is that the police were permitted to do something (search through garbage bags) that nobody else could lawfully do. The second key issue is that the police could do this without any specific authorization or justification - the finding that there was no reasonable expectation of privacy meant that there was no search and therefore no constitutional basis for imposing judicial oversight of any kind or placing limits on the exercise of discretion in

\footnotetext{
${ }^{43}$ Patrick, supra note 2 at para 67 for the requirement of confidentiality to attend a disclosure to third parties. ${ }^{44} \mathrm{Ibid}$ at para 55.

${ }^{45}$ As pointed out by Justice Abella in her concurring judgement, the City of Calgary Waste Bylaw, 20M2001 "prohibits scavenging, dictates the location of the waste and controls what is to be placed in the receptacle." Ibid at para. 87. She takes this as evidence of an "objectively reasonable expectation that household waste will be gathered by the garbage collection system once it is left at the pickup site." (At para 88.)
} 
choosing whose garbage to open and in what circumstances. From the perspective of a narrow understanding of privacy, this decision can be defended; from the perspective of basic rule of law values, this result is deeply troubling.

Another clear example of the idea of "expectations" expanding rather than limiting the discretionary authority of the police is in $R v$ Gomboc. As outlined earlier, this case concerned the constitutionality of the use of a DRA device to record electricity consumption patterns in the home. A majority of the Supreme Court found that the information recorded either met the biographical core test of s.8 or was the kind of "specific and meaningful information" discussed earlier that still attracts constitutional protection. However, several of these judges nonetheless held that there was no overall reasonable expectation of privacy because of the legal effect of a regulation that permitted the utility company to share customer information with the police unless the customer indicated a desire for confidentiality. According to Justice Abella:

The fact that the customer can request that his or her information be protected means essentially that under this Regulation, the customer is presented with the unrestricted ability to control the expectation of privacy in his or her relationship with Enmax. A request by a customer to prohibit disclosure of customer information revokes the legislative authority for its disclosure. Mr. Gomboc made no such request, yet urges the Court to treat his expectation of privacy as if he had. ${ }^{46}$

${ }^{46}$ Gomboc, supra note 1 at para 85 (Binnie and LeBel JJ concurring). 
The framework of expectations of privacy is, again, notable for how it shapes the significance of the regulation. If we moved to a more explicit rule of law framework, the issues look quite different.

For example, as already discussed, one key aspect of the rule of law is fair notice. It is difficult to see how — as the Chief Justice and Justice Fish describe it in dissent — "an obscure regulation that the reasonable person is unlikely to understand" would meet the requirements of fair notice, especially if the effect of this regulation is to essentially turn an unreasonable search into a reasonable one. ${ }^{47}$ Equally disturbing is the fact that this regulation was not an authorization for the police to install a DRA device. It was not even an authorization for the utility company to install a DRA device, as it only permitted them to voluntarily share customer information. Far from permitting the police to do what private citizens are able to do, or even permitting the police to do what private citizens are unable to do (as in Patrick), the Court here allows a provincial regulation to empower police agents (the utility) to do what neither the police nor private citizens are otherwise permitted to do. ${ }^{48}$ From the perspective of placing constraints on the arbitrary exercise of discretion, this decision is quite shocking. Its effect is to permit provincial governments to pass little-known regulations that change the existing state of the law and thereby permit a new form of surveillance by third parties, the exercise of which is entirely a matter of police discretion. ${ }^{49}$

\footnotetext{
${ }^{47}$ Ibid at para 142.

${ }^{48}$ See McLachlin CJC and Fish J: "In our view, the regulatory scheme should not be interpreted to authorize police agents to act in a manner forbidden to the police themselves." Ibid at para. 148.

${ }^{49}$ Abella J does suggest that the accused should have challenged the constitutionality of the regulation.
} 
What these cases highlight is that the idea of "expectation" is being used to limit constitutional protection in a manner that is reminiscent of the "risk analysis" arguments that were rejected by the Supreme Court more than 20 years ago in a trilogy of electronic surveillance cases. ${ }^{50}$ If you place your "bag of information" by the road, or if you fail to avail yourself of a little-known regulation, then you place this information out of your control and take the risk of having this information obtained by others, including the police. It is worth remembering that a concern for unfettered police discretion was one of the key concerns that Justice La Forest raised in relation to the surreptitious electronic surveillance at issue in those cases. ${ }^{51}$ For example, in addition to his many statements regarding privacy as well as ideas of freedom, La Forest states that it is "inconceivable that the state should have unrestricted discretion to target whomever it wishes for surreptitious video surveillance. ${ }^{, 52}$ Although LaForest frames his analysis in terms of privacy, his arguments in the trilogy of cases are replete with references to concerns for unrestrained police discretion and the potential for "random fishing expeditions" that it raises. Subsequent jurisprudence focused instead on La Forest's statements regarding the nature of privacy. It is time to return instead to a focus on rule of law values in order to provide a more robust, and non-distorting, legal framework for their expression.

In moving towards a stronger rule of law focus, it is important to refer to core rule of law values and not simply one or two standard articulations. As I have outlined, one such standard articulation is that, absent special authorization, the police are not permitted to do what others are not permitted to do (such as trespass). If this is seen as the rule of law concern, then there are

${ }^{50} R v$ Duarte, [1990] 1 SCR 30, dealing with participant surveillance; $R v$ Wong, [1990] 3 SCR 36, dealing with video surveillance; $R v$ Wise, [1992] 1 SCR 527, dealing with a tracking device installed on a car.

${ }^{51}$ Ibid.

${ }^{52}$ Wong, supra note 51. 
ways of meeting this concern that still might not address all rule of law considerations. For example, the Canadian government has been promising to reintroduce its lawful access legislation, one component of which would require telecommunication service providers to give subscriber information to the police upon demand and without a warrant. ${ }^{53}$ If we are only concerned with the question of whether the police have special authorization to do something (gain access to subscriber information) that people are generally not permitted to do, ${ }^{54}$ then passing legislation that provides this authorization would appear to solve the rule of law problem. However, if this authorization is in fact an authorization to engage in broad and highly discretionary fishing expeditions then we could instead argue that rule of law concerns have not been met by such authorization - they have merely been displaced only to reappear in relation to other elements of such a regime.

The rule of law concerns that remain in relation to the proposed lawful access legislation have to do with the fact that state access to subscriber information does indeed make an individual vulnerable to state power in the way that the Supreme Court of Canada is starting to note in its "specific and meaningful" test for "private" information. Often, the police seek access to subscriber information because they have evidence of criminal activity in relation to a particular IP address and want to match this to a street address in order to get a search warrant for someone's home and, hopefully, computer. ${ }^{55}$ Access to this information can also help the police

\footnotetext{
${ }^{53}$ Bill C-52, Investigating and Preventing Criminal Electronic Communications Act, 3rd Sess, 40th Parl, 2010, s 16, first reading November 1, 2010. This bill died on the order paper but is expected to be reintroduced.

${ }^{54}$ Disclosure of such information to ordinary citizens is prohibited under Personal Information Protection and Electronic Documents Act, SC 2000, c 5 (PIPEDA).

${ }^{55}$ There have been a series of cases regarding whether the police can get access to subscriber information without a warrant in the absence of legislation like the proposed lawful access legislation and many of these follow such a fact pattern. See: $R v$ Kwok, [2008] OJ No 2414, 78 WCB (2d) 21; $R v$ Ward, 2008 ONCJ 355, [2008] OJ No 3116; $R v$
} 
to identify individuals and their activities online when they might prefer to remain anonymous.

This means that access to subscriber information can make individuals vulnerable to serious state intrusions in their lives. Of course law enforcement requires that the state get access to such information. But the rule of law demands that such access occur within a legal framework of accountability that constrains the arbitrary exercise of discretion and prevents abuses. Merely "authorizing" access to this information without an accompanying structure of oversight does not make such a regime consistent with our core rule of law commitments. The public debate regarding such surveillance proposals would be helped by moving away from a focus on whether subscriber information is indeed "private" information and toward a focus on questions of accountability and oversight.

\section{Conclusions}

Legal arguments, and in particular constitutional arguments, will always be only partial tools for addressing social issues such as new forms of surveillance. But they remain important given the central role that the idea that a proposal is "Charter-proof" has in public policy debates. The claim that proposed legislation is Charter compliant is often offered as a definitive argument that there is nothing problematic about such proposals. As the Canadian government moves forward with controversial initiatives such as the proposed lawful access legislation, the current narrowness of Charter understandings of privacy can help to legitimate these plans and support the augmentation of police powers of surveillance. While continuing to critique constitutional

Friers, 2008 ONCJ 740, [2008] OJ No 5646; $R$ v McGarvie, 2009 CarswellOnt 500 (Ont CJ); $R$ v Verge, 2009 CarswellOnt 501 (Ont CJ); $R$ v Vasic, [2009] OJ No 685, 185 CRR (2d) 286; $R v$ Cuttell, 2009 ONCJ 471, [2009] OJ No 4053; $R v$ Trapp, 2009 SKPC 5, [2009] SJ No 32; $R v$ Wilson, [2009] OJ No 1067 (available on Quicklaw); $R$ $v$ McNeice, 2010 BCSC 1544, [2010] BCJ No 2131; $R$ v Brosseau, 2010 ONSC 6753, [2010] OJ No 5793. 
ideas of privacy is important, I have argued here that reviving the rule of law roots of search and seizure jurisprudence can provide a powerful alternative legal lexicon for naming the problems associated with this increase in the discretionary authority of law enforcement officers. 